\title{
GLOBAL CHALLENGES AND NEW APPROACHES IN THE COMMON AGRICULTURAL POLICY 2014 - 2020
}

\author{
GLOBÁLNE VÝZVY \\ A NOVÉ PRÍSTUPY V RÁMCI \\ SPOLOČNEJ POLNOHOSPODÁRSKEJ POLITIKY \\ V ROKOCH 2014 - 2020*
}

Gabriella BÁNHEGYI**

\section{Introduction}

The future that not so much time ago seemed to evolve into a continuous development and increasing prosperity of the people of the world is getting more and more unpredictable and full of confusion. Economic, environmental, social and political uncertainties, challenges mark our present and the widely celebrated new century brought more questions than answers. What will happen to our Planet Earth, will there be enough natural resources to fulfill our and our children's need, can we avoid economic crisis, and can we maintain global peace? Or war is unavoidable triggered by the depleting supply of non-renewable energy resources, of food, and scarcity of water? How can we provide enough food for the ever growing human population? How can we avoid ecological catastrophes? How should we deal with the threat that global climate change is bringing in our way? Can we stop the unfavorable or downright dangerous events, can we find the solution? Is there a solution at all? This paper examines some of the most pressing global challenges and some of the answers given by the European Union. The paper gives

\section{Abstract (EN)}

Unfavorable environmental issues raise attention globally toward the concept of sustainability. Agriculture is not only a sector influenced greatly by environmental conditions, but at the same time, as the most important utilizer of land, a major shaper of the environmental conditions. When forming agricultural policies special attention should be paid to issues such as climate change, scarcity of fresh water, food shortage and biodiversity loss - just to name some of them. The new European general strategy for the upcoming 7 years period has brought new measures for the agricultural policy as well, environment and sustainability being among the top issues.

\section{Keywords (EN)}

climate change, biodiversity, Europe 2020 strategy, common agricultural policy, green component of the CAP a brief review of the reasoning and possible effects of the so called greening of the Common Agricultural Policy, though it should be emphasized that the CAP changes are related to the changes that take place in the overall EU strategy. Can the new measures bring breakthrough in biodiversity protection, or is it a failure? What do the stakeholders think?

\section{Material and methods}

This paper is a humble synthesis of the different studies, surveys and opinions concerning the topic, along with some statistics and the possible effect on Hungarian agriculture and environment. Secondary sources had been studied and processed and this paper wishes to be no more than a debate launching effort by revealing those arguments and facts that surround and influence the present agricultural policy.

The author examines the following areas:

a) Is there a common understanding worldwide that new measures are to be introduced in agricultural production for the sake of sustainability?

b) Do the EU's new agricultural policy reform bring fore

\section{Abstrakt (SK)}

Nepriaznivá environmentálna situácia pritahuje, v globálnom meradle, čoraz väčšiu pozornost' ku konceptu udržatel'nosti. Pol'nohospodárstvo nie je len sektor výrazne ovplyvňovaný životným prostredím, ale kedže je najvýznajmnejším užívatelom pôdy, vo velkej miere tiež formuje environmentálne podmienky. Pri tvorbe polnohospodárskych politík by mala byt' zvýšená pozornost' venovaná problematikám ako klimatické zmeny, nedostatok vody a potravín a tiež biodiverzite. Nová európska stratégia pre nasledujúce sedem ročné obdobie prináša aj nové opatrenia pre polnohospodársku politiku, pričom životné prostredie a udržatel'nost' sa radia medzi najdôležitejšie témy.

\section{Klúčové slová (SK)}

klimatické zmeny, biodiverzitam, stratégia Európa 2020, spoločná polnnohospodárska politika, zelený prvok SPP

" The paper has been published in the Volume Proceeding: „Výzvy a perspektívy Agrárneho práva EÚ“ Jean Monnet Chair [CD]. Nitra: Slovak University of Agriculture in Nitra, p. 203. ISBN 978-80-552-1200-5

** University of Pannonia Georgikon Faculty 
fundamental changes that can contribute to the sustainability in the long run?

c) Is it possible to harmonize member states', producers, consumers' and environmental interests within the EU?

It is important to note that this paper is not a thorough analysis of the future CAP, and not all the measures are taken into account, but it pays attention only to the green component.

\section{Results and discussion}

Global challenges influencing agriculture related legislature

What are the most pressing issues in the World? There are quite many that can be mentioned. While writing this paper the international media is full of news about the military conflicts between Israel and the militant islamists of the Hamas, Muslim Brotherhood, and there is no wonder that the attention focuses on this area of our globe. A prolonged military conflict in the Middle East will by all means influence the whole world's energy supply. A fallen apart Syria, a weakened Egypt, with Iraq is in turmoil, Saud and Iran fighting each other - there are no stable governments who could balance the scales. The United States seems losing interest - partly you would think because they are creating energy independency - in the region, former players also are lacking the eagerness (or money) to intervene, to smooth present events. Since energy supply is at stake, probably some powers will try to navigate the conflict and we cannot be sure in the (positive) outcome. However strictly focusing on the topic of the paper the prolonged conflict easily can result in sharp price rise of crude oil, which will result in rising costs of production, processing, transporting. And possibly in a greater attention paid to renewable energy sources that can boost the production of energy crops.

While not forgetting that an escalating military conflict would change priorities to attend to in the world, there are some other pressing matters and almost all of these are connected to the sustainable development. These are fresh water, food, biodiversity, climate change - possibly climate change being the core issue today. So what can we discover about them?

Before discussing the different elements of this section, it cannot be avoided to remember the famous study initiated and led by Meadows: „The limits to growth" published by the Group of Rome. In their study Meadows et al found that maintaining industrial output, food production, population growth at the 1972 levels would result eventually in the collapse of human populations due to pollution, lack of food, etc. (see the different scenarios of the research) and the final outcome is that unless industrial output led economic growth is stopped (zero growth) the collapse of ecological conditions and eventually human population is unavoidable. The computed model sent the message that only through serious measures of environment protection can sustainability be maintained. The 1972 study was followed by more and the conclusion is somewhat depressing: in spite of the warning necessary political measures are rarely adequate. The core scientific message of the research was emphasized by
Randers later, as the popular message seemed to overwhelm the communication. This scientific message read like this: "Global society is likely to overshoot - and then be forced to decline or collapse - because of significant reaction delays in the global economy. These are the unavoidable lags in the perception and localization of global limits, the significant institutional delays involved in (democratic) decision-making, and the biophysical lags between implementation of remedial action and the improvement of the ecosystem ${ }^{(1)}$. The upcoming studies emphasized the result of the original 1972 report: once the overshot is reached (business as usual scenario), collapse is on the way. And we are in that stage already.

How agriculture is related to the concept of the research? Agricultural production is the main source of food supply. The growing human population requires increased food production, which leads to rising food prices, and in response to intensive production technologies, increased land demand. Converting land to intensive agricultural production means increased pollution and degrading soil quality which results later in food shortage. Therefore is seems plausible to control agricultural land use, apply appropriate measures to prevent soil degradation.

\section{Climate change}

The majority of governments accept - at least theoretically - that there is a changing (warming) climate that is caused mostly by the vast emission of greenhouse gases, especially of carbon dioxide. Since the second half of the twentieth century international committees, panels, United Nation organizations examined the process and finally in 1992 in the framework of the Rio Conference on Environment and Development (Earth Summit) they signed (though its discussion run separately from the Summit and started earlier, in 1988 with the establishment of the International Panel on Climate Change; IPCC) a Convention on Climate Change with the goal of returning their greenhouse-gas emissions to "earlier levels" by the turn of the century ${ }^{(2)}$. An important recognition also became part of the global environment protection efforts and policy, namely that global problems require global approach. Global environmental issues have the feature of spreading from places they originate to other places (like pollution), they can have prolonged effect on the environment (like GH emission) and often solutions that seems fine when launching them prove dangerous as well later. Since there are huge differences among countries in economic strength, research capacity, and social attitude it seemed only right that climate change studies should run under the umbrella of the UN. Different scenarios were modelled by either the IPCC, or other non-UN bodies, published, debated regularly, from them a brief summary of IPCC scenarios and findings:

(1) Randers, J.: What was the message of the Limits to Growth? what did this little book from 1972 really say about the global future? Club of Rome, 2010. pp 12.

(2) Parson, E. A. - Haas P. M. and Levy M. A. (1992): A summary of major documents signed at the earth summit and the global forum. Environment 34 (4): 12 - 15, 34 - 36. 
Graph 1: Climate change effect

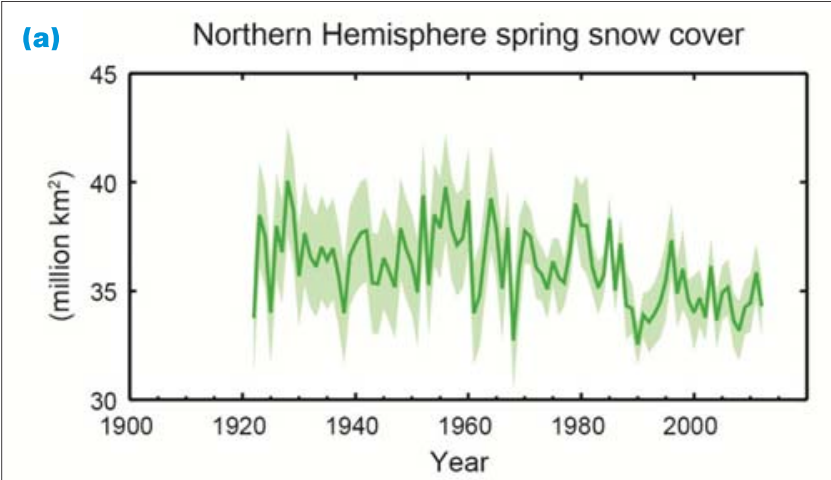

(c) Change in global average upper ocean heat content

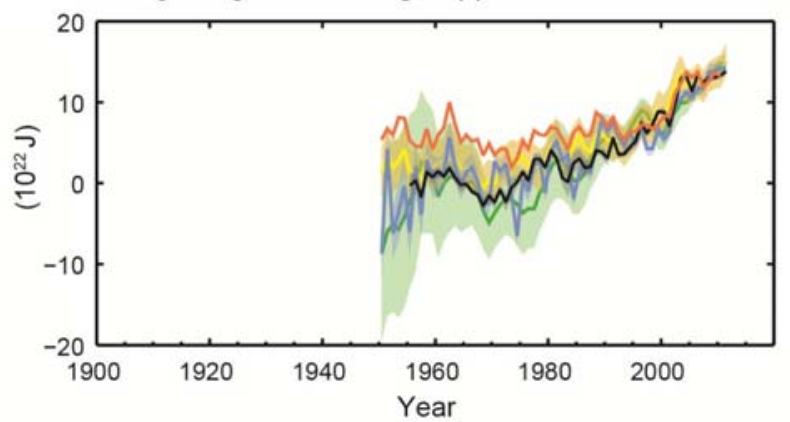

(b) Arctic summer sea ice extent

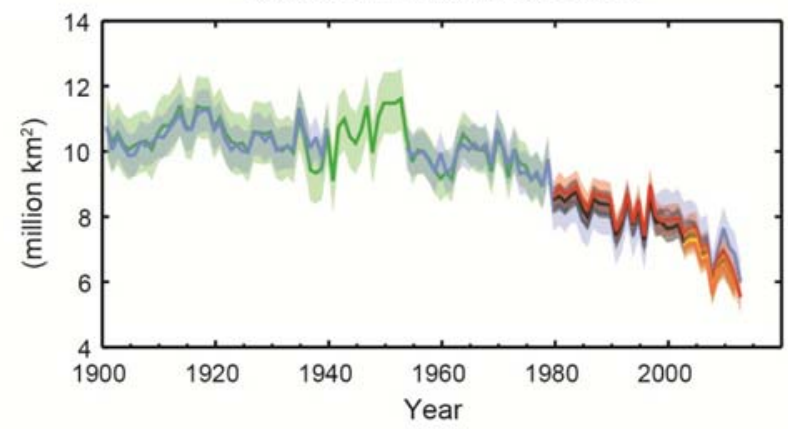

(d)

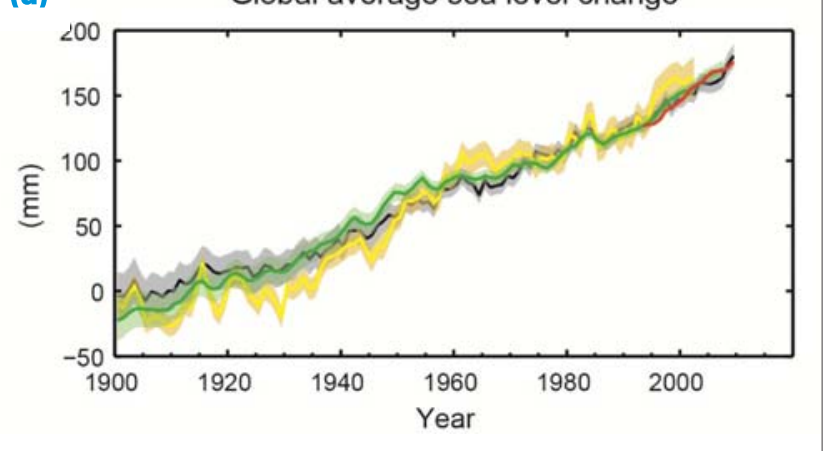

Source: IPCC Report, 2013

The IPCC introduced 4 "storyline" which generates four sets of scenarios, altogether 40 scenarios, called Special Report on Emission Scenarios (SRES) - since global climate change is highly influenced by GH emission. The storylines include $\mathrm{Al}$ ) very rapid economic growth with new and more effective technologies, population peak in the middle of the $21^{\text {st }}$ century followed by population decline; A2) a very heterogeneous world with self-reliance and protection of local identities, slower but steady population growth; B1) same population tendencies as in the Al storyline, but rapid changes toward a service and information oriented economy, introduction of clean and resource-efficient technologies - global solutions for economic, environmental and social sustainability; B2) local solutions on economic, social and environmental sustainability, global population growth rate is lower than in A2 storyline. The greatest problem with any forecast is of course the uncertainty of the future events, therefore it is almost impossible to estimate the probability of any of the scenarios. Short and long term climate change projections are strongly related to the changes in GH emission levels, and due to space limitations they cannot be discussed here, but it is strongly recommended to read the short version of the IPCC report of 2013.

Graph 1 is presented from the report just to show some of the main findings, facts of observations: You can notice the shrinking snow cover, and arctic ice, the increasing heat content of oceans, and the rise of sea level.

The IPCC report summary (for policy makers) emphasizes among the others that the warming of the climate system is unequivocal, that each of the last three decades has been suc- cessively warmer at the Earth's surface than any preceding decade since 1850, that over the last two decades the Greenland and Antarctic ice sheets have been losing mass, glaciers have continued to shrink almost worldwide, the atmospheric concentrations of carbon dioxide, methane and nitrous oxide have increased to levels unprecedented in at least the last 800, 000 years. Carbon-dioxide concentrations have increased by $40 \%$ since pre-industrial times. The main source of emission is fossil fuel and second significant source is the change of land use - another warning about the need of measures concerning land use. It is very important to note, that the role of human influence on the climate system is extremely likely to be the most dominant cause of observed warming since the mid $-20^{\text {th }}$ century ${ }^{(3)}$.

Another important finding is that average global temperature rising cannot be stopped by even the strictest measures on $\mathrm{GH}$ emission reduction, depending on the scenarios the most probable version of average global surface temperature rising ranges from $1,5^{\circ} \mathrm{C}$ (all scenarios) to over $2^{\circ} \mathrm{C}$. Climate change has an impact of the water cycle as well, and different regions will experience different changes in precipitation - appropriate forecast for the regions are available and later we will have a look at the changes forecasted in the case

(3) IPCC, 2013: Summary for Policymakers. In: Climate Change 2013: The Physical Science Basis. Contribution of Working Group I to the Fifth Assessment Report of the Intergovernmental Panel on Climate Change [Stocker, T.F., D. Qin, G.-K. Plattner, M. Tignor, S.K. Allen, J. Boschung, A. Nauels, Y. Xia, V. Bex and P.M. Midgley (eds.)]. Cambridge University Press, Cambridge, United Kingdom and New York, NY, USA. 
of Hungary. And the final conclusion of the report is very sobering: most aspects of climate change will persist for many centuries even if emissions of $\mathrm{CO}_{2}$ are stopped (it is because carbon-dioxide cumulates in the atmosphere).

What is the relation between agriculture and climate change? As the majority of suitable landed are has been converted into agricultural production two important changes occurred: the carbon absorbing capacity of the green areas (forest) decreased, and these same areas (land) started to produce more GH gases due to the cultivation (mainly from fertilizers), and animal husbandry (digestion and manure management). On EU-27 (2011) level the estimated GH emission of the agriculture exceeds 10 percent, and if we observe different $\mathrm{GH}$ gases, the emission of $\mathrm{N}_{2} \mathrm{O}(57 \%)$ and $\mathrm{CH}_{4}(43 \%)$ is the highest in the agriculture of all sectors. ${ }^{(4)}$

\section{Fresh water supply}

About $70 \%$ of the Earth surface covered with water which might sound reassuring until we add that this cover is very thin compared to the size of the globe, and only 2,5\% of this water volume is fresh water that is essential for life. Going further it is also important to know that even from that fresh water supply about $68 \%$ is closed in ice sheets and glaciers, a further $30 \%$ is in the ground and only $1,2 \%$ of it is easily accessible surface freshwater. After all the fresh water supply is really not that big to start with and the problem is that the growing human population needs more and more of it. In the $20^{\text {th }}$ century water consumption increased six-fold, at more than twice the rate of population growth ${ }^{(5)}$ and almost one-fifth of the global population live in areas of physical scarcity ${ }^{(6)}$. We drink it; we use it for other purposes, e.g. the energy sector, transportation, or industry. With the changing climate very unfavorable changes can occur in the supply of fresh water. UN estimation says that present water supply is enough for about 7 billion people but the distribution of course is uneven and there are problems with pollution and water management.

And don't forget, agriculture is one of the greatest user of fresh water. If global warming means that in certain regions draught periods will be more frequent and lengthened then agriculture will need water for irrigation even in those places where it was not necessary in the past.

\section{Food supply}

Probably it is not really necessary to give detailed discussion about the relations among population, food demand, and agriculture. It is very clear that a growing world population require more food and that food is produced primarily by the agricultural sector. Increasing demand can lead to the introduction of more intensive production methods, which would lead to soil degradation and (underground and sur-

(4) Lovas K., Kis-Kovács G. (2011): A mezőgazdaság üvegházhatású gáz kibocsátása. Országos Meteorológiai Szolgálat Üvegházgáznyilvántartási Osztály, 2011.

(5) United Nations, Human Development Report 2006, UNDP 2006.

(6) FAO (2008) Coping with water scarcity-An action framework for agriculture and food security, Food and Agricultural Organization of the United Nations, Rome 2012, pp 100. face) water pollution. New hybrids, breeds can give more yield but they are usually more sensitive and require more fertilizers, pesticides (plant cultivation), or antibiotics, higher protein content feed, etc. in animal husbandry) which can have a negative effect on human health.

According to population forecasts, by 2050 the world's population is expected to reach 9 billion. There is basically no more land that can be converted to agriculture and water scarcity only adds to the problem. Sustainable intensification is needed and suitable technologies including agro technology and biotechnology are studied already. ${ }^{(7)}$

\section{Biodiversity}

Biodiversity means the variety of life on the Earth. One might think at first read that it is really not so important but that would be a mistake. Since biodiversity is basically a vast genetic pool, any loss of that pool mean permanent and irreversible loss of life. We should not forget that our food comes from plants and animals that was bred from some wild ancestors (approximately 35 animal species were domesticated and about 7000 plants were cultivated for consumption in human history -according to the Food and Agriculture Organization of the United Nations, FAO.) What is more a loss of e.g. a plant species will have an impact on the entire food chain and affects the whole ecosystem. Presently we know that there is a steady loss of biodiversity globally and there are many international agreements, treaties, strategies to control, stop or turn back the process. Since agriculture is the main user of land its connection to biodiversity loss is very evident.

\section{Sustainable agriculture à la European Union - new CAP elements}

\section{The wider framework of the Europe 2020 Strategy}

Before giving any details about the new changes in the European Union's Common Agricultural Policy (CAP) we should note that it is embedded in the wider European 2020 strategy. This strategy addresses five headline targets that cover employment, R\&D, climate/energy, education, social inclusion and poverty reduction. To achieve the major goals seven flagship initiatives have been launched including sustainable growth that means a low-carbon and more efficient sustainable utilization of the available resources; environment protection by preventing biodiversity loss and reducing pollution; developing new green technologies and production methods; increasing consumer awareness; smart electricity grid; improving business environment especially for SME-s; and harnessing EU-scale networks.

Directly environment related EU targets are (20-20-20 targets)

- 20\% reduction in GH gas emissions by 2020 (compared to 1990 levels) - also a further commitment from the

(7) Rosegrant M. W. - Koo J. - Cenacchi N. - Ringler C. - Robertson R. - Fisher M. - Cox C. - Garrett K. - Perez N. D. - Sabbagh P. (2014): Food security in a world of natural resource scarcity the role of agricultural technologies; International Food Policy Research Institute, Washington, USA 
EU to go further and make a 30\% reduction if developed and developing countries contribute also.

- Renewable energy sources provide $20 \%$ of final energy consumption by 2020 .

- Moving toward an energy efficiency increase of $20 \%$.

As these targets are part of the overall EU strategy, consequently they have to appear in all policy area, including the CAP, energy policy, transport policy, regional and rural development policy, etc. The CAP had to be harmonized with the Europe 2020 strategy and further harmonization ensured to meet the goals with the EU biodiversity strategy for 2020 .

\section{Greening the CAP}

The European Commission prepared proposals for the necessary CAP measures and they were presented in 2011. It also should be mentioned that there were several scenarios drafted prior to the finally chosen "greening" one, including the status quo and the drastic withdrawal of agricultural supports. The final proposal included a basic shift in the approach to agricultural supports, but at the same time it should not be forgotten that the CAP already had some components that has a "greening" nature - like cross compliance measures, or special support (e.g. agri-environment schemes) from the European Agricultural Fund for Rural Development (EAFRD). From the major changes - details are discussed below - it seems that the greatest problems to be addressed are biodiversity, carbon-dioxide emission (climate change), shrinking rural life, and food-safety. The problem is that environment protection and providing public goods not necessarily go along with the food-production, food-security goals. It is a task for agricultural economists to model and analyze the possible outcome.

The most characteristic feature of the reform is that greening becomes compulsory across the EU for all farmers. The green component to be met can vary depending on the type of farming, but basically affects all farmers.

\section{New CAP legislation}

New legislation on the direct payments - establishing rules for direct payments to farmers under support schemes within the framework of the common agricultural policy and repealing Council regulation (EC) No 637/2008 and Council Regulation No 73/2009 - in CAP I. pillar was adopted on 17 December 2013 with Regulation (EU) No 1307/2013 of the European Parliament and of the Council. Three other regulations also was adopted about market measures (Regulation 1308/2013), rural development (Regulation 1305/2013) and horizontal issues (Regulation 1306/2013).

Important change occurred concerning farmers who are entitled to direct payments: the concept of active farmer means a natural, or legal person, or groups of natural or legal persons, whose agricultural areas are mainly areas naturally kept in a state suitable for grazing or cultivation and who do not carry out on those areas the minimum activity defined by Member States or operate airports, railway services, waterworks, real estate services, permanent sport and recreational grounds. [Article 9 (1-2)], however Member States can give to this list or can apply exemptions as well.

The former measure represents very well the difficulties of European mandatory legislation; with so many different countries of different conditions, diversified agricultures: rigid rules will not enhance competitiveness, will not encourage farmers, so the scope of Member States should be improved. However, too much scope would result in a non-common agricultural policy and it is a serious issue (see arguments about the so called re-nationalization of the CAP).

The original Commission proposals were amended on several points upon the opinion and suggestion of the Council and Parliament. Original proposal and final legislation will be marked in the text.

The final outcome is highly debated, farmers organization find it too green, while green organizations find it not so green at all. Joined bodies of different green organizations demand more public good for the public funding the CAP benefits from. Different authors are expressing different views about the benefit from greening.

An important rule (article 38) is that organic farms - for those units of the farm that fulfil the conditions laid down in Council Regulation (EC) No 834/2007 (the rules of organic production and labelling of organic products) are entitled the benefit from the greening component without needing to fulfil any further obligations.

Meeting the greening is compulsory; farmers who fail to respect the requirements face penalties. According to the original proposal failure to meet the mandatory requirements would have evoked a double penalty, which was refused by the Parliament in 2013 March.

Along with the introduction of green components rules of cross compliance have been changed as well, however farmers still have to meet the rules of both Statutory Management Requirements (SMRs) and Good Agricultural and Environmental Conditions (GAECs).

According to the accepted regulation(s) 30\% of the direct payments will be transferred to the farmers, if they apply production methods that are favorable in terms of climate abd enviroment.

Green components: proposal, final regulation and their possible impact in the Hungarian agriculture

1. Crop diversification: According to the original proposal farmers would have been entitled to $30 \%$ of the Pillar I. payments if they had three different crops on their arable land (in case if arable land covers more than three hectares and not entirely used for grass production). The reasoning behind diversification is to offset the development of monoculture. It is thought that increased crop diversity brings biodiversity benefits.

Hungary - along with other countries and the European Parliament recommended to raise the 3 hectares limit to 10 hectares with only two crops to produce between 10-50 hectares, and argued that the rule would make the survival of small farms impossible.

Green organizations such as the Wildlife Trust argued that the excepted benefits are very limited and the proposal discourage low intensity arable cropping though it is essential for the survival of plants, mammals and birds. A three crops requirement would result in bringing more 
land in production.

The finally adopted regulation requires crop diversification over only 10 hectares of arable land. At least two crops should be produced if the arable land is not larger than 30 hectares and is not entirely left fallow or entirely cultivated with crops under water for a significant part of the year. The main crop cannot cover more than $75 \%$ of the arable area.

Over 30 hectares at least three different crops should be produced and the main crop should not cover more than $75 \%$, the two main crops together not more than $95 \%$ of the arable land.

There are also some exceptions to the rule concerning large ratio of permanent grasslands, forage area, geographical conditions.

The original proposal would have posed a problem to about 35 thousand farmers (most (of them managing smaller crop farms) according to the calculations of the Hungarian Research Institute of Agricultural Economics. With the adopted new area requirements Hungarian farmers took a more favorable position.

2. Permanent grassland: According to the Commission's proposal farmers should have maintained as permanent grassland the areas of their holdings declared as such for claim year 2014. Permanent pasture measures were two fold till 2013. It included a requirement to be met at national level of not changing permanent pasture area ratio in the total agricultural area with more than $10 \%$ compared on the baseline period, and there was GAECS measure about maintaining permanent pastures, the latter is to be met on farm level. Neither the original proposal, nor the adopted legal text is difficult for Hungary to perform.

Opposing green organizations thought that the proposal was weak as maintaining permanent grassland is not equals with protecting it or enhancing its quality.

3. Ecological focus area: According to the Commission's proposal farmers should have ensured that at least $7 \%$ of their eligible hectares, excluding areas under permanent grassland, is ecological focus area such as land left fallow, terraces, landscape features, buffer strips and afforested area.

Hungary debated that this ratio is too high and would affect badly $90 \%$ of the Hungarian farmers, resulting in significant income loss. Suggestions had been made to either reduce the 7 percent to 3; or/and let the requirement to be fulfilled at national level and not at the farm level. The European Parliament also recommended a 3\% threshold.

The adopted regulations state that where the arable land of a holding covers more than 15 hectares, the farmer shall ensure that, from 1 January 2015, an area corresponding to at least $5 \%$ of the arable land of the holding shall be ecological focus area (EFA). The percentage shall be increased from $5 \%$ to $7 \%$ subject to a legislative act of the European Parliament and of the Council. By August 2014 Member states can decide to classify land lying fallow, terraces, landscape features, buffer strips, supported agro-forestry areas, strips of eligible hectares along for- est edges, areas of short rotation coppice with no use of mineral fertilizers and/or plant protection products, afforested areas, areas with catch crops or green cover established by the planting and germination of seeds and areas with nitrogen fixing crops as EFA. There are also some exemptions from the measure.

\section{Expected environmental benefits}

It might be disappointing but according to some experts the benefits will be very limited if there will be benefits at all due to the diluted final version of the original and more ambiguous proposal. All of the green components the EFA measures are of the possibly highest immediate environmental benefits by improving biodiversity and improving water and soil quality. As there are many exemptions and Member State decision dependent rules, which can be satisfied e.g. by classifying landscape elements as EFA, and there is no requirement that would force farmers to follow environmentally beneficial everyday practices, the overall impact of the reform on the environment will not be significant. Supporters think that even if benefits are miniscule the reform still is an important step toward a new green approach in agricultural policy. We can be sure that agricultural economists, farmers, and green organization will follow, measure, assess and discuss the impacts of the reformed CAP.

\section{Summary}

Global challenges require global cooperation, and solutions tailored to meet regional, local conditions and possibilities. The global environment is under serious pressure caused mostly by human activities. The most serious problems include climate change, water scarcity, food shortage, biodiversity loss just to mention a few. Some of them are not necessarily pose an acute problem worldwide (such as food shortage mostly affects people in the developing countries) others mean global threat (such as climate change). Since the second half of the 20th century international efforts have been made to find global solution to the problems. International agreement, treaties have been born and by all means some level of global cooperation has been introduced.

The EU is a unique entity, with 28 member states transferring part of the sovereignty to the EU institutions. As the EU legislation has a direct and binding effect in member states, the EU is a very good example, might say a forerunner of regulated globalization. Therefore mandatory requirements can be examined concerning their immediate and long term effects concerning the benefits for the environment. The greatest problem of the EU legislation is the difficulty of establishing thoroughly effective regulation, as agriculture is a much diversified sector in the Community with different ecological conditions and production methods in the member states. Due to the nature of the decision making process (the proposal of the Commission have to be approved both by the Parliament and the Council) it is inevitable to make compromises and often it results in a diluted and much less effective outcome. What is more the conflicting interests of farmers and environmental organizations can be hard to harmonize, just as it happened with the greening of the CAP, 
which deemed to be unnecessarily difficult and harsh on farmers and at the same time lacking the ability of bringing favorable changes in the environmental conditions.

\section{References}

1. FAO (2008) Coping with water scarcity-An action framework for agriculture and food security, Food and Agricultural Organization of the United Nations, Rome 2012, pp 100.

2. Parson, E. A. - Haas P. M. and Levy M. A. (1992): A summary of major documents signed at the earth summit and the global forum. Environment 34 (4): 12-15, 34-36.

3. Randers, J.: What was the message of the Limits to Growth? what did this little book from 1972 really say about the global future? Club of Rome, 2010. pp 12.

4. Rosegrant M. W. - Koo J. - Cenacchi N. - Ringler C. - Robertson R. - Fisher M. - Cox C. - Garrett K. - Perez N. D., Sabbagh P. (2014) : Food security in a world of natural resource scarcity - the role of agricultural technologies; International Food Policy Research Institute, Washington, USA

5. IPCC, 2013: Summary for Policymakers. In: Climate Change 2013: The Physical Science Basis. Contribution of Working Group I to the Fifth Assessment Report of the Intergovernmental Panel on Climate Change [Stocker, T. F. - D. Qin, G.-K. Plattner, M. Tignor - S. K. Allen - J. Boschung - A. Nauels - Y. Xia - V. Bex and P. M. Midgley (eds.)]. Cambridge University Press, Cambridge, United Kingdom and New York, NY, USA.

6. Lovas K. - Kis-Kovács G. (2011): A mezőgazdaság üvegházhatású gáz kibocsátása. Országos Meteorológiai Szolgálat Üvegházgáz-nyilvántartási Osztály, 2011.
7. Matthews A. (2012) Greening the CAP: the way forward. Paper prepared for the 126th EAAE Seminar, Capri, Italy June 27-29, 2012. downloaded 2014.07.13.: https://docs.google.com/ file/d/0B6Koz bJBQHYSUZTOFZ fWkhxeVu/edit

8. Meadows D. - Meadows D. H. - Randers J. - Behrens W. W.: The Limits to Grow - A report for the Club of Rome's project on the predicament of mankind (1972), Universe Books, New York, 1972.

9. United Nations, Human Development Report 2006, UNDP 2006.

10. Europe 2020, an European strategy for smart, sustainable and inclusive growth - communicatrion from the Commission (2010), European Commission, Brussels 3.3.2010 COM (2010) 2020.

11. Regulation (EU) No 1307/2013 of the European Parliament and of the Council of 17 december 2013 - establishing the rules for direct payments to farmers under support schemes within the framework of the common agricultural policy and repealing Council Regulation (EC) No 637/2008 and Council Regulation (EC) No 73/2009 - donwloaded 2014. July 10 from website http://eur-lex.europa.eu/LexUriServ/LexuriServ.do? uri=OJ:L:2013:347:0608:0670:EN:PDF

12. Wildlife Trust webpage and discussion on the possible effect of the greening of the CAP . donwloaded 2014. July 9 from webpage http://www.wildlifetrusts.org/CAP

\section{Contact address/ Kontaktná adresa}

Gabriella Bánhegyi PhD.

University of Pannonia Georgikon Faculty, Department of Economics and Social Sciences, Deák F. u. 16, 8360 Keszthely, Hungary

E-mail: banhegyi@georgikon.hu 